\title{
Pemelekan and Pengebugan: representation of the strengthening of social species of female and male gender through gangsing games
}

\author{
Luh Putu Sendratari ${ }^{1}$; I Ketut Margi ${ }^{2}$ \\ $\left\{\right.$ lpsendra@yahoo.co.id $\left.{ }^{1}\right\}$ \\ Universitas Pendidikan Ganesha, Indonesia ${ }^{1,2}$
}

\begin{abstract}
Gangsing in Pedawa village has the potential as a vehicle for the formation of social species of female and male genders. The purpose of this research is to find out the symbol and meaning contained in the games that represent the construction of gender social species. This research uses a qualitative approach. Data for this research are obtained from primary sources (interview and observation) and secondary sources (literature review). Descriptive analysis and critical analysis are used to answer the research question. Using Paul Ricoeur's hermeneutic theory in the context of gangsing as a social text, this research learns the meaning of life as a man and woman from the perspective of the Pedawa people. This research concerns language and symbols in the gangsing game. Gender symbols in gangsing are evident in the dimensions of language, shape and color, and game patterns. The meanings found in the game are persistence, strength, and satisfaction. The conclusion of research is that the patriarchal masculine elements are dominant in the game, obscuring feminine element. This research will have implications for strengthening understanding of gender construction sociocultural
\end{abstract}

Keywords: Traditional Game; Pemelekan; Pengebugan; Ngebom; Gender Species

\section{Introduction}

Today's traditional games have become something that is beginning to be ignored by the wider community, especially the younger generation. This cannot be separated from the influence of the swift currents of globalization and increasingly advanced technological developments. One of the advances in technology is the creation of various modern games, one of which is a playstation with various types of games in it. As a result, our young generation is too busy playing these modern games[1].

Yet if we look at traditional games besides providing fun and entertainment, it turns out that they contain a lot of value, especially character education. However, traditional games also have a lot of interest, one of them is gender species. This case can be seen in many traditional games in Bali. Games seem to have gender species, namely men's games and women's games. In fact, the game is actually made to meet the entertainment needs of children or adults who are bored with their daily activities[2]. One of the traditional games in Bali that is interesting to examine 
is the game of gangsing in Pedawa village, which divides the game equipment into two, namely Pemelekan and Pengebugan as representations of men and women.

This study aims to learn about the symbols and meanings of gangsing as a form of social text. In his book, Hermeneutics and The Human Sciences, Ricoeur[3] defines hermeneutics as "the theory of the operations of understanding in their relations to the interpretation of text" [1]. The extended meanings of a text influence the interpretation of discourses other than written text. Paul Ricoeur, for example, extends the concept of text to any deliberate action to achieve certain goals. According to Ricoeur, discourse is different from language as a system (langue). Discourse stems from the exchange of meanings in speech events. Discourse consists of four elements: the subject that expresses content or proposition, which is the depicted world, the address it is aiming at, and the context (space and time). In discourse, very complex and meaningful traffic occurs.

The institutionalization of traditional games in Bali is not new. There are at least two sanggar (studios) in Bali that preserve traditional games: Sanggar Kukuruyuk, managed by I Made Taro, and the Pasraman Budi Pekerti Institution "Sri Tanjung" in Bunutin Bangi Village under I Nengah Suardana. These sanggar popularize traditional games for children so they can learn character values. Many examined sanggar and their activities [4], [5], focusing on exploring the values of national character in traditional Balinese children's games. However, the traditional game of gangsing is not included in the object of study even though it is not only for entertainment. In terms of semiotics, gangsing represents the strengthening of the social gender species of women and men.

Gangsing, a work of art examined from a hermeneutical perspective, can be used as a guide [6] on using hermeutic reading to understand the text through the following hermeutic methodology scheme.

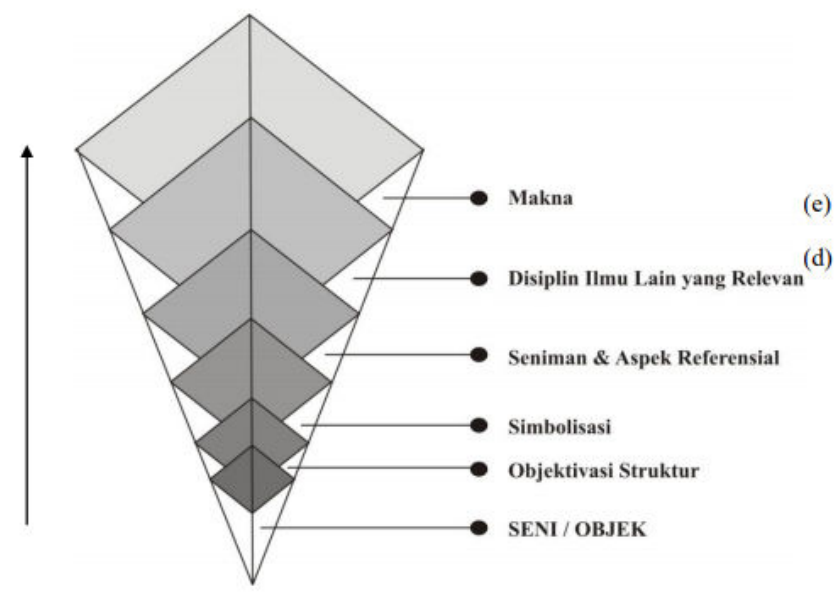

Source: [6]

From that all, this study aims to learn about the symbols and meanings of gangsing as a form of social text. Especialy this research is to find out the symbol and meaning contained in the games that represent the construction of gender social species.

\section{Method}

This study uses qualitative methods, supported by critical analysis. Data are obtained from 
primary sources, collected from informants selected by purposive sampling. The key informant in this research is Pak Wayan Sukrata (65 years old). Meanwhile, Irwan Sutarto, Made Karya, Pak Rusia, Pak Wayan Dolat, and Nyoman Rawi are additional informants. Interviews and observations were conducted within the framework of the triangulation of data sources. Data analysis was done using a hermeneutical scheme, supported by critical analysis.

The data collection process was carried out by conducting in-depth interviews with key informants. After that, the data collected was confirmed to other informants. The entire data is then synchronized with the data from the observation source. The observation activity was carried out by observing the gangsing game in the Pedawa village. It also observes the preparation process and other activities related to research. The results of interviews and observations were then analyzed with documentary data from other research studies.

The whole process takes place interactively until the data is declared saturated. In the analysis process, the researcher uses various hermeneutic approaches, with critical theory as the analysis guide. The whole process aims to obtain a holistic and emancipatory research result.

\section{Result and Discussion}

\section{The Symbols and Meanings of Gender in Gangsing}

Gender is not just a biological difference (sex and body) between men and women[7]. The differences also concern actions, appearance (gesture, clothes, and styles), and behaviors that become the identity of men and women. They are constructed by the historical course of human social interaction with norms or conventions, accustomed and enforced in the socio-cultural environment [8].

As a gender construction, the findings show that gangsing, as an object and a game, contains powerful gender elements. These elements manifest in language, shape or color, and game patterns. They are elaborated in the following.

Table 01. Elements of Language in the Gangsing Game

\begin{tabular}{lll}
\hline Terms & Definition & Meanings \\
\hline Pemelekan & Under & $\begin{array}{l}\text { The name for female gangsing. It is thrown first } \\
\text { to be hit by the pengebugan gangsing. In the 70s, } \\
\text { this gangsing is given decoration, as looking } \\
\text { beautiful is a requirement for this gangsing. The } \\
\text { rotation of the pemelekan gangsing conveys a } \\
\text { sense of beauty. }\end{array}$ \\
\hline Pengebugan & Hitting from above & $\begin{array}{l}\text { The name for male gangsing. It serves to beat the } \\
\text { pemelekan gangsing. It is associated with } \\
\text { strength, toughness, agility, concentration, and } \\
\text { balance. }\end{array}$ \\
\hline Seet & $\begin{array}{l}\text { Choosing the first player } \\
\text { through a round of gangsing to } \\
\text { start the game }\end{array}$ & $\begin{array}{l}\text { Conciliator } \\
\text { The ultimate action using prime } \\
\text { strength }\end{array}$ \\
\hline Ngebom
\end{tabular}

Language play is a cultural practice in gangsing games. Following the domination theory, women's and men's languages are different in terms of power. The difference in power between women and men is the primary cause of the variations in the resulting discourse [9]. This context results in the "sexist discourse," which shows the power over women [10]. The terms "under," 
"above," "hitting," "ngebom" are sexist discourses. Patriarchal society is full of symbol play under the umbrella of patriarchal ideology. The patriarchal ideology places men at the center of the social system, while women are on the periphery. Men are in superordinate positions, while women are in subordinate positions. It implies that not only do men dominate women but also hegemonize them. It is relevant to Antonio Gramsci's thoughts on how gender inequality originated from cultural hegemony.

Behind a language, there always be power play [8]. It means that language occupies a strategic position for spreading the ideology behind it. Language can also presuppose a particular mode of power in every language practice (choice of words, style of expression, vocabulary, and knowledge), expressed or concealed by the status of the language. Therefore, language becomes so essential for individuals and groups to achieve, preserve, and even fight against domination. According to Bourdieu, language is not just a means of communication that includes a set of meaningful words in the process of understanding. A language can also turn into an instrument of violence, which exploits the symbolic universe in the network of power.

\section{Elements of Shape and Colors}

The shape of the pemelekan gangsing is more pointed, while the pengebugan is oval. The following is the form of gangsing.

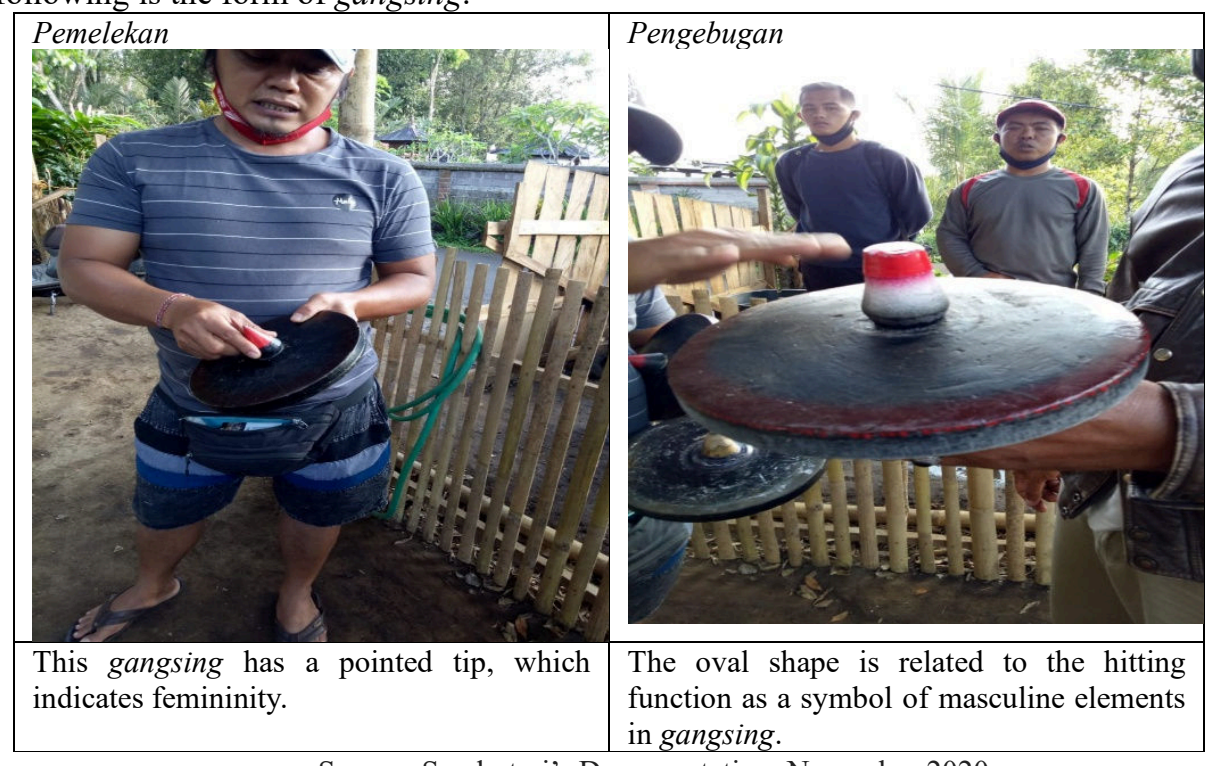

Source: Sendratari's Docomentation, November 2020

\section{Elements of Game Patterns.}

Gender is important (if not the most important) factor in the social development of game culture [11]. Therefore, the game design will determine the strength of the gender content in the game pattern. In the gangsing game pattern, there are three masculine elements: taking stances, throwing, and hitting. These three are the main elements in the game pattern. The following is a picture of those elements in the game pattern. 

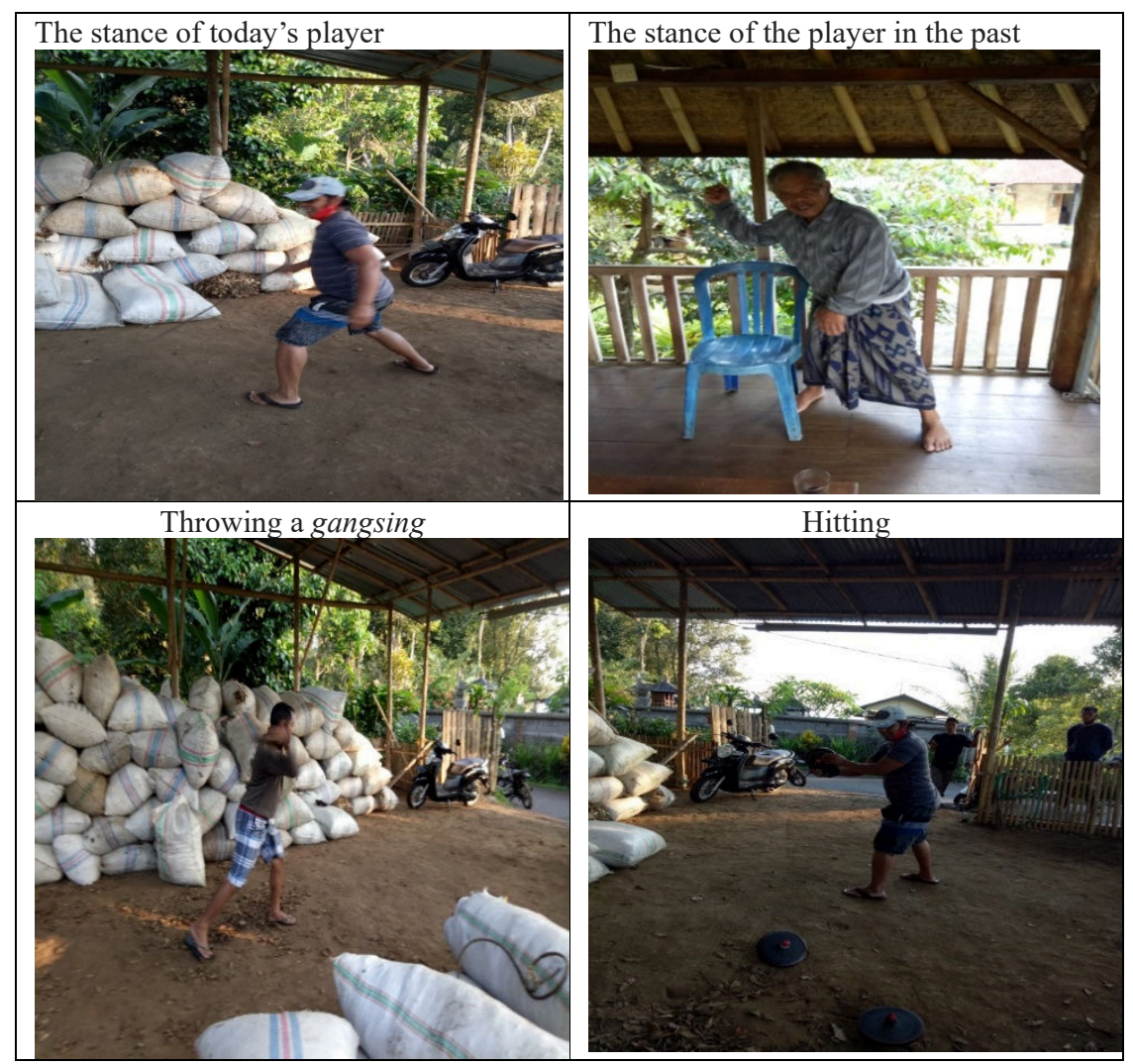

Source: Sendratari's Documentation, November 2020

Taking stance, throwing, and hitting are constant design in gangsing game. These designs represent the powerful masculine element of the game. It is apparent in the spread legs (male gender) and the throwing action (male gender stereotype). The hitting action also represents the male gender. The design makes the gangsing game appear to represent masculine elements. It explains the exclusion of women from the game. The meanings that dominate the gangsing game are strength, persistence, and satisfaction. These aspects are viewed as masculine elements, which are associated with the male gender. This perception shapes the understanding of the Pedawa people, who believe that the gangsing game is only for boys when the game cycle adopts a female symbol [12].

The gangsing game contains binary elements about the characteristics of women and men. However, if interpreted comprehensively, the gangsing game conveys masculine and feminine elements as a unity, inseparable from the game. These elements have their contribution to the game. The overemphasis on masculine elements results in a male-biased view. The marginalization of feminine power in this game is a cultural practice that commonly appears in gender construction [13]. It is evident in the informant's interpretation of the meanings of gangsing: persistence, strength, and satisfaction. These elements are the dominant elements that shape the understanding of the Pedawa people that gangsing is a female game. Gender bias in the game is also evident in the pemelekan, in which women are represented as weak people. It is this context that highlights gender bias in games. This result is similar to findings of studies on traditional gender-based games that contain gender bias, such as the market game, the 
cooking game [14]. It contrasts with the findings of studies on dolanan, which has high equality values[1] [15] .

According to essence traditional games have noble values as well as certain moral messages, such as shared values, honesty, responsibility, broad-mindedness, achievement, and obedience to the rules. All will be obtained if the player really enjoys, enjoys, and understands the meaning of the game [11]. In this context, gangsing is provides more opportunities for man to build moral massages in traditional games.

When compared with literary works have the same function as traditional games as value transformation, through feminist literary criticism there are works of literary in which the placement of women is inversely related to traditional games on gangsing. Children's literary works that were born after 2000s show female figure tend to be positive with the spirit of girl power [12]. The game of gansing can be positioned as a work of art that can be transformed like any other work of art. Through the theoretical perspective developed by Maruska Spasek, Judih Butler, and several related writers, it was found that the traditional art of Topeng Ireng underwent a transformation which work marked by changed in objects that had transition in a new location or owner, namely the material or forms of slimming art patterns. The changes that occur show transitions in several aspect, including content represented through art form and gender performative. This means that a work of art is very flexible to change, including gangsing games.

\section{Conclusion}

For the Pedawa people, the gangsing game has historical value. The myth about the god Kumara, and the tradition on the making of pelangkiran kumara, which includes gangsing for baby boys and young coconut for baby girls, are the philosophical basis for the strong construction of male gender in the gangsing game. The symbols in gangsing that concern gender comprises of three elements: language, shapes, and the game pattern. The meanings in gangsing are strength, persistence, and satisfaction. The masculine elements in the gangsing game overshadow the feminine elements, which results in the perception that this game is only for boys. However, the obscurity of the feminine elements in the gangsing game does not affect the strength of the Pedawa women in religious and adat activities. Their strength lies in their ability to make tools for religious ceremonies.

\section{Acknowledgements}

I would like to that the Head of LP2M Undiksha and staff; Pak Wayan Sukrata; Irwan Sutarto, Made Karya, Pak Rusia, Pak Wayan Dolat, Nyoman Rawi, and my colleague, Wayan Sadnyana for their support for the completion of this research.

\section{References}

[1] A. S. Rahmatulla, "Internalisasi Nilai Gender melalui Dolanan Anak Tradisional," J. Pendidik. Islam, vol. 3, no. 2, hal. 365, Des 2014, doi: 10.14421/jpi.2014.32.365-388.

[2] M. Y. Hamdani, "Permainan anak-anak di kecamatan conggeang kabupaten sumedang (Kajian Struktural dan Etnopedagogik)," LOKABASA, 2015, doi: 10.17509/jlb.v6i2.3162.

[3] P. Ricoeur dan J. B. Thompson, Hermeneutics and the Human Sciences. Cambridge: Cambridge University Press, 1981. 
[4] M. Priyatna, "Pendidikan karakter berbasis kearifan lokal," Edukasi Islam. J. Pendidik. Islam, 2017, doi: 10.30868/ei.v5i10.6.

[5] I. N. Suarka, Nilai Karakter Bangsa dalam Permainan Tradisional Anak-anak Bali. Denpasar: Udayana Press, 2011.

[6] A. Saidi, "Hermeneutika, Sebuah Cara Untuk Memahami Teks," J. Sosioteknologi, vol. 7, no. 13, hal. 376-382-382, 2008.

[7] S. D. Maharani, "Peran Perempuan dalam Hubungan Antar Gender: Tinjauan Filsafat Moral terhadap Otonomi Manusia," J. Filsafat, vol. 13, no. 1, hal. 86-94, 2007, doi: https://doi.org/10.22146/jf.31277.

[8] B. Allegranti, "The politics of becoming bodies: Sex, gender and intersubjectivity in motion," Arts Psychother., vol. 40, no. 4, hal. 394-403, Sep 2013, doi: 10.1016/j.aip.2013.05.017.

[9] S. Wareing, "Language, Society and Power: An Introduction," in Language and Gender, London \& New York: Routledge., 2015, hal. 65-78.

[10] Y. Rahyani, A. Utarini, S. A. Wilopo, dan M. Hakimi, "Predictors of premarital sexual initiation on adolescents in Bali: a longitudinal study," BMC Public Health, 2014, doi: 10.1186/1471-245814-s1-o25.

[11] M. CONDIS, Gaming Masculinity: Trolls, Fake Geeks, and the Gendered Battle for Online Culture. Iowa city: University of Iowa Press, 2018.

[12] Y. Jiang, R. Bachner-Melman, S. H. Chew, dan R. P. Ebstein, "Dopamine D4 receptor gene and religious affiliation correlate with dictator game altruism in males and not females: evidence for gender-sensitive gene $\times$ culture interaction," Front. Neurosci., vol. 9, Sep 2015, doi: 10.3389 /fnins.2015.00338.

[13] N. E. Saputra dan Y. N. Ekawati, "Meningkatkan Kemampuan Dasar Anak Tradisional Games in Improving Children 'S Basic Abilities," J. Psikol. Jambi, vol. 2, no. 2, hal. 48-53, 2017.

[14] H. W. Kusuma, M. Asmawi, H. Hernawan, F. Dlis, dan I. N. Kanca, "Physical Activity Development.Model.Using Traditional Balinese Game in Junior High School," PENDIPA J. Sci. Educ., vol. 4, no. 1, hal. 40-46, Feb 2020, doi: 10.33369/pendipa.4.1.40-46.

[15] D. Rosikhoh dan A. Abdussakir, "Pembelajaran Pola Bilangan melalui Permainan Tradisional Nasi Goreng Kecap," J. Tadris Mat., vol. 3, no. 1, hal. 43-54, Jul 2020, doi: 10.21274/jtm.2020.3.1.43-54. 